\title{
Stipulation in Contract from Islamic and Malaysian Legal Perspectives
}

\author{
Norhoneydayatie Abdul Manap ${ }^{1}$, Hayatullah Laluddin ${ }^{1}$, Zuliza Mohd Kusrin ${ }^{1}$, Ahmad Dahlan Salleh ${ }^{1}$, Mat Noor \\ Mat Zain ${ }^{1}$, Ahmad Muhammad Husni ${ }^{1}$, Nik Abdul Rahim Nik Abdul Ghani ${ }^{1}$ \& Anwar Fakhri Omar ${ }^{1}$ \\ ${ }^{1}$ Department of Shari'ah, Faculty of Islamic Studies, National University of Malaysia, Malaysia \\ Correspondence: Norhoneydayatie Abdul Manap, Department of Shari'ah, Faculty of Islamic Studies, \\ National University of Malaysia, Malaysia. E-mail: norhoney@ukm.my
}

Received: July 22, 2013 Accepted: November 20, 2013 Online Published: December 29, 2013

doi:10.5539/ass.v10n2p112 URL: http://dx.doi.org/10.5539/ass.v10n2p112

\begin{abstract}
Generally, a subject of legal obligation is bound to perform his/her obligation regardless of whether the source of the obligation comes from the Lawgiver or is initiated by the subject of the law himself. Contract is a source of obligation which is initiated by a subject of legal obligation. Therefore, a person who makes a contract is responsible to the contract he concludes. Thus he is obliged to observe and perform his duty as agreed upon in the contract. In some cases, additional conditions or stipulations are included in the contract. Theses stipulations or conditions present a form of obligation that has to be complied with by contracting parties. The purpose of this study therefore, is to examine whether additional conditions can be added into the contract from the perspective of Islamic law and Malaysian law or otherwise. Thus, this study attempts to elaborate on the concept of stipulations its nature and types from Islamic and Malaysian laws points of view. The study also analyzes the similarities and differences of the concept of stipulations between both laws. The study uses comparative and analytical methods. The finding of the study shows that the term of stipulation and its types in Islamic law and Malaysian law are similar. Therefore, it is suggested that the contracting parties before making any stipulation to their contract to seek the advice of experts in order to make sure their contract is according with the law and is Shari'ah compliant.
\end{abstract}

Keywords: stipulations, obligation, Islamic, law

\section{Introduction}

A subject of legal obligation is legally obliged to perform his duty which is imposed upon him. It is the rule of an obligation, whether it is originated from the textual sources of the law or is imposed by a subject of the law himself to perform it. There are many sources of obligation; contract is portrayed as one of such source in the legal framework. Therefore, any person making a contract is responsible to observe and fulfill the terms of the contract that he or she has concluded. In other words, he/she is obliged to observe and perform his duty as agreed under the terms of contract. In some cases, parties to the contract put some additional conditions or stipulations within the framework of the contract they intend to conclude for instance, when A says to B, "I will pay you RM500.00 if you find my ring." Then B agreed to it. The stipulation or condition which is mentioned in the contract constitutes a form of obligation that obliged the parties to obverse it.

Thus, this paper attempts to delineate the theory of stipulation (shart) under Islamic Law of obligation in comparison with the common law. Definition of the stipulation, types of stipulation and the effect of obligation are also discussed in this paper.

\section{Authorities of Stipulation under Islamic Law and Common Law}

Islamic Law as well as the Common Law recognizes the theory of stipulation (shart). Under the Islamic Law, the authorities of the theory of stipulation (shart) can be found in the Quran and also in the Hadith. Allah said in the Holy Quran, "O you who believe! Fulfill your contracts." (Note 1)

Besides this Qur'anic verse, there is a Hadith in which it is stated, "Muslims are bound by their conditions except a condition which allows what is prohibited or prohibits what is lawful." (Note 2)

In addition to these authorities there are others authorities regarding the principles of obligation, either stated in the primary sources of Islamic Law i.e. the Quran and Sunnah or stated in the secondary sources of Islamic Law 
such as the Majallat al-Ahkam al- 'Adliyyah. Many countries in the Middle East apply the principles of obligation as stated in the theory of stipulation and is well recognized under the common law, the Section 38 of Contracts Act 1950 provides that "The parties to a contract must either perform, or offer to perform their respective promises, unless the performance is dispensed with or excused under this Act, or of any other law."

From these legal provisions provided by Islamic Law and Common Law it becomes clear that the principle of obligation is directed to the people and they have the duty to perform and observe it.

\section{Definition of Stipulation (Shart) under Islamic Law}

Generally, the meaning of stipulation (shart) in Muhit dictionary is to obligate to something. (Note 3) Al-Wasit dictionary defines the stipulation (shart) as an arrangement of a condition above the other conditions with some tool such as whether or when etc. (Note 4)

According to Abdul Karim Zaidan, stipulation (shart) is an essential mark or a sign or an indication. He extends the definition of stipulation (shart) as something upon which the existence of something else depend, and its existence does not necessarily lead to the existence of something else but its nonexistence lead to its nonexistence. (Note 5)

According to Mohammad Hashim Kamali, a stipulation (shart) is an evident and constant attribute whose absence necessitates the absence of the hukm but whose presence does not automatically bring about its object (mashrut). For example, the presence of a valid marriage is a precondition of divorce, but it does not mean that when there is a valid marriage, it must lead to divorce. Another example, the ablution (wudhu') is a necessary condition of salah, but the presence of wudhu' does not necessitate salah. (Note 6)

Kamali further explains; a condition normally complements the cause and gives it its full effect. For instance, killing is cause of retaliation; however this is on the condition that it is deliberate and hostile. Another example is the contract of marriage which legalizes or causes sexual enjoyment between the spouses; however this is on the condition that two witnesses testify to the marriage. Here, the legal consequences of a contract are not fully realized without the fulfillment of its necessary conditions. (Note 7)

Muslim Scholars define the stipulation in two different ways. First, they defined the stipulation (shart) as an obligation or a commitment on an act which exceed from the command of the original act, regardless of whether that extra obligation require performance or none performance, or whether the act is beneficial to the person who is obliged to perform it or is beneficial to others, for example, the obligation of a buyer with stipulation (shart) in the contract of sale, requiring the handing over of the soled item and its delivery to the seller. Here, the original act or the original obligation is that the seller gives the item to the buyer and the buyer pay the payment or the price of the item to the seller. Then, the extra obligation imposed on the seller here is to deliver the item to the buyer. The scholars named the stipulation as defined in this sense as shart al-muqayyad which means limited or restricted stipulation.

Second meaning of stipulation (shart) as provided by Muslim Scholars, is an extra command pertaining substantive lawful act, which existence depends on the existence of the stipulation (shart), and which nonexistence is also due the nonexistence of the stipulation (shart). For example, someone says that if he succeeds in examination he will give charity to the poor. The scholars named this as shart mu'allaq (suspended stipulation). (Note 8)

From the given definitions of stipulation (shart), the preferred definition for the purpose of discussion is the definition of Kamali.

\section{Meaning of Stipulation under Common Law}

According to Collins English dictionary, the word 'stipulation' is derived from stipulate which means to specify, often as a condition of an agreement, or to insist on as a term of an agreement. Literally, stipulation means condition or term of an agreement. The legal meaning of stipulation according to Law Dictionary is a material condition or requirement in an agreement especially a factual representation that is incorporated into a contract as a term. (Note 9)

Under Malaysian Law of Contract, stipulation refers to the term, content, provision, covenant or clause of the contract; depending on the nature of the particular contract. Stipulation of contract basically means a statement of fact or a promise which forms an essential term of the contract. (Note 10)

Legally, 'condition' means a voluntary agreement between opposing parties concerning some relevant points i.e., the Plaintiff and Defendant entered into a stipulation on the issue of liability. According to Vohrah and Aun, the term 'condition' in the ordinary use of the word, it may be used to describe any of the following; 
1) The occurrence or non-occurrence of an uncertain event which has been agreed by the parties to have a particular result. For instance, when A says to B 'I shall give you \$50 if you find the ring that I lost yesterday'. Finding the lost ring is the condition precedent to the formation of the contract.

2) To describe any term of a contract.

3) An important term of a contract the breach of which gives rise to the right to terminate the further performance of the contract.

In this sense, a condition may be distinguished from a warranty which is also a term of a contract but its breach would give rise only to a right to damages and not a right to terminate the further performance of the contract. (Note 11)

According to Lord Reid, in the House of Lords in L Schuler AG v. Wickman Machine Tool Sales Ltd (1974) AC 235;

"In the ordinary use of the English language 'condition' has many meanings, some of which have nothing to do with agreements. In connection with an agreement it may mean a pre-condition: something which must happen or should be done before the agreement can take effect. Or it may mean some state of affairs which must continue to exist if the agreement is to remain in force.

The authors believe the legal meaning of condition would not occur to a layman for being beyond his comprehension and its understanding requires familiarity with legal terms and concepts. Thus, a condition in that sense is not something which has automatic effect. It is a term the breach of which by one party gives to the other party the option of either to terminate the contract or to let the contract proceed and, if he so desires, sue for damages for the breach."

Section 12 (2) of the Sale of Goods Act provides that, "a condition is a stipulation essential to the main purpose of the contract, the breach of which gives rise to a right to treat the contract as repudiated."

According to Lord Denning M.R. in the case of Wickman Machine Tools Sales Ltd. v. L. Schuler A. G. (1972) 1 WLR 840, "A stipulation in a contract which carried with it this consequence: if the promisor breaks a 'condition' in any respect, however slight, it gives the other party a right to be quit of his future obligation and to sue for damages."

The stipulation also includes warranty. As stated under Section 12 (1) of Sale of Goods Act 1957, "a stipulation in a contract of sale with reference to goods which are the subject thereof may be a condition or a warranty."

Legally, 'warranty' means express or implied promise that something in furtherance of the contract. (Note 12)

Under Section 12 (3) Sale of Goods Act, "a warranty is a stipulation collateral to the main purpose of the contract, the breach of which gives rise to a claim for damages but not to a right to reject the goods and treat the contracts as repudiated."

According to Vohrah and Aun, a term of condition or warranty really depends on the intention of the parties. It is not conclusive in labeling a particular term. A stipulation may be condition though called a warranty and vice versa. (Note 13)

From the above definitions it can be concluded that the term of stipulation have a wide range of meanings which include term, condition, warranty and etc.

\section{Comparison between Islamic Law and Common Law}

There are similarities between the term of stipulation (shart) under Islamic Law and Common Law. Under the definition, the term of stipulation (shart) include condition, and it gives the meaning of the existence of the act depends on the existence of the stipulation (shart), and non-existence of the act because of non-existence of the stipulation (shart), or the occurrence or non-occurrence of an uncertain event which has been agreed by the parties to have a particular result.

Furthermore, under the Malaysian Law of Contract, stipulation refers to the term, content, provision, covenant or clause of the contract which is dependent on the nature of the particular contract. It is also stated under the Islamic Law in reference to the meaning of the stipulation (shart) as an extra command pertaining the original act either requiring performance or non-performance of an obligation. This type of stipulation is of such a nature that complements the cause and gives it full effect.

\section{Types of Shart under Islamic Law}

From the above definitions of stipulation one can conveniently classify stipulation into the following categories: 
Condition that is laid by the Lawgiver, or by the Mukallaf. Kamali, holds that whenever the Lawgiver enacts a condition, it is referred to as a shart shar' $i$, or 'legal condition', but if it is stipulated by the Mukallaf, it is referred to as shart ja'li, or 'improvised condition'. Example of shart shar' $i$ is the witness in a marriage contract, whereas, the example of shart ja'li is the stipulation by the spouse in the contract of marriage that they will have to reside in a certain locality. (Note 14)

Similarly, Abdul Karim Zaidan, divides the stipulation into two types. First type is legal stipulation (shart shar' $i$ ) In the legal stipulation (shart shar'i) the source to make stipulation (shart) is Allah. Allah is who make a condition to realize or accomplish something. For instance, in the case of handing over property to the person who had attained the age of majority (baligh), it can be said that in this type the stipulation is made by Allah and cover all actions, worships and felonies. (Note 15)

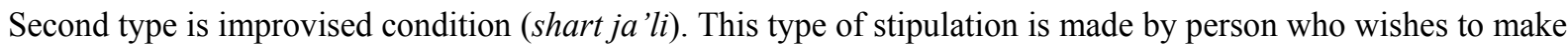
it, for example, the stipulation made by people themselves in undertaking of an act or making of a contract. This category of stipulation can be divided into two types.

First, shart ta' 'liq, this is a type in which the existence of the contract is made dependent on the stipulation. This means, the person making a real contract make its realization dependent on the existence of the stipulation he has made. For example, suspension of guaranty on the inability of debtor to pay loyalty or suspension of divorce upon some conditions such as husband telling his wife, if you steal I will divorce you. Thus, the stipulation (shart) is known as suspended shart (shart mu'alaq) and the contract is known as suspended contract ( $a^{\prime} q d$ muallaq).

Second, shart taqyid, is a stipulation which is joined with the contract, for example, the stipulation of wife having the right to divorce, in the contract of marriage and the stipulation of residence for a year, in the house in the contract of sale. (Note 16)

Mahmassani, also divides stipulation (shart) into two types i.e. shart ta'liq and shart taqyid. From the forgoing discussion it becomes clear that, majority of the Muslim scholars divided stipulation (shart) into two categories i.e. the stipulation made by Lawgiver (Allah) and the stipulation made by parties involved in the contract.

\section{Types of Stipulation under Common Law}

Stipulation in the common law also is divided into two types, under the appellation, precedent condition and subsequent condition.

Precedent condition is the type of stipulation which requires suspension of the operation of an obligation or right until the happening of a certain event. Thus, if the event never happens, the obligation or right never arises. (Note 17) It can be observed in the case of Pym v. Campbell (1856) 6 E\&B 370. In this case the defendant agreed in writing to buy from the plaintiff a share in an invention. The defendants gave oral evidence that it was not to be operated until a third party had approved the invention, and that this had not happened. The court held that there was a condition precedent which had not been satisfied and the plaintiff could not recover.

Second type of condition under common law is condition subsequent. Under this type the obligation of one or both parties may be subject to the condition that it is to be immediately binding. However in the event of a certain occurrence or the ascertaining of certain facts, the obligation will cease to be binding or the party will have the rights to avoid the contract. (Note 18) In the case of Head v. Tattersall (1871) LR 7 Ex 7, A bought a horse from $\mathrm{B}$ with a certain description. A was to have the right to return it by a certain day if it did not match its description. The horse not matching the description was returned by A before the day. In the meantime, the horse had been injured without A's fault. The court held that the contract had been brought to an end by the fulfillment of the condition subsequent. A was entitled to recover the price, and the loss occasioned by the horse's injury fell on $\mathrm{B}$.

\section{Comparison between Islamic Law and Common Law}

There are certain similarities and differences between Islamic Law and Common Law in respect of the types of stipulation. In Islamic Law, there are two types of stipulation that come from the lawgiver. The first one is called shart shar' $i$ or 'legal condition' which is set by the Lawgiver, Allah. The common law also has this category of stipulation called legal condition which is set by the legislative branch of the government. Second type is shart $j a$ 'li, or 'improvised condition' which comes from the contracting parties. This is the same under the common law which come from the contracting parties.

Both Islamic Law and Common Law acknowledge the two types of stipulation (shart). First, the Islamic Law has shart ta'liq, where the existence of the contract is made dependent on the existence of the stipulation. Similarly, 
the common law has the condition precedent, where an obligation or a right is made dependent on the happening of a certain event, if the event never happens; the obligation or right never arises.

Second, in Islamic Law there exists shart taqyid, which is jointly addressed with the contract. Here, the content of the contract must not be against the Shari'ah. While it is the same under the Common Law, known as condition subsequent, where, the obligation is subjected to the condition that it is to be immediately binding. Under this type, the content of the contract must not be against law or not against any public policy.

\section{Conclusion}

Stipulation in contract being as a form of obligation is equally recognized in Islamic legal framework as well as common law. Such recognition by both laws implies that the parties involved in a contract are permitted to stipulate additional condition in their contract. However, such stipulation should fulfill certain criterion as required by Islamic and common laws, in terms of not being in contradiction to the legal principles and being Shari'ah compliant.

Consequently, agreement of the contracting parties to additional condition necessitates the obligation of observing and performing it as agreed upon. Therefore, they are obliged to observe their duty of fulfilling the terms of their contracts, hence not violating them. Failure to fulfill the terms and conditions of the contract results in legal consequences. It means that if one of the contracting parties fails to observe the terms of the contract, the losing party has the right to claim the damage caused as a result of violation of the stipulated conditions. Henceforth, it is advisable for the contracting parties to seek the advice of legal experts before adding any stipulation or condition to the contract to insure its consistence with the law. This especially significant for the Muslim to insure their stipulation is in accordance with Shari'ah principle, hence obeying the commandment of Allah SWT.

\section{References}

Agarwal, V. K. (2001). Law of Contract (Principles and Practice). Kuala Lumpur: International Law Book Services.

Al-Sagoff, S. A. (1996). Principles of the Law of Contract in Malaysia. Malaysia Law Journal.

Contract Act. (1950). Employment Act 1955.

Kamali, \& Mohammad, H. (2009). Principles of Islamic Jurisprudence (2nd ed.). Ilmiah Publishers.

Majallat, A. A., \& Hamat, M. A. A. (n. d.). The Theory of Option (al-Khiyar) in Islamic and Malaysian Laws: A Comparative Study. Kuala Lumpur: Unpublished Master Dissertation, International University Malaysia.

Muhammad, A. H. (1984). Al-Ishtirat Li-Maslahat Al-Ghayr Fi Al-Fiqh Al-Islami Wa Al-Qanun Al-Muqaran. Sharikat Maktabat 'Ikad Lilnashar wa attauzi'.

Templeman, L. (1997). Obligations: Contract Law. Old Bailey Press.

The Holy Quran, \& Khattab, T. W. (1983). Ahkam Al-Iltizam Baina As-Shariah Al-Islamiyyah Wal Qanun. Darul Fikr Al-'Arabi-Al-Qahirah.

Vohrah, B., \& Aun, W. M. (2003). The Commercial Law of Malaysia. Pearson Malaysia Sdn. Bhd.

Wahbah, A. (2003). Al-Figh al-Islami wa Adillatuh (Vol. 4 \& 5). Dar al-fikr, Damascus (3rd ed.). (Translated by Mahmoud A. El-Gamal into English "Financial Transactions in Islamic Jurisprudence" (Vol. 1). Dar al-Fikr, Damascus, (1st ed.).

Zaidan, A. K. (1985). Al-Madkhal Li Dirasat Shari'ah Islamiah. Maktabah Al-Quds.

Zaidan, A. K. (2006). Al-Wajiz fi Usl al-Fiqh. Muassasah Ar-Risalah Nashirin.

\section{Notes}

Note 1. Qur'an, Surah Al-Maidah, p. 1.

Note 2. Bukhari Muslim.

Note 3. 'Abbas Husni Muhammad, 1984, Al-Ishtirat Li-Maslahat Al-Ghayr Fi Al-Fiqh Al-Islami Wa Al-Qanun Al-Muqaran, Sharikat Maktabat 'Ikad Lilnashar Wattauzi', p. 21.

Note 4. Ibid, p. 21.

Note 5. Zaidan, Abdul Karim, 2006, Al-Wajiz fi Usul al-Fiqh, Muassasah Ar-Risalah Nashirin, p. 46. 
Note 6. Mohammad Hashim Kamali, 2009, Principles of Islamic Jurisprudence (2nd ed.). Ilmiah Publishers, pp. 337-338.

Note 7. Ibid. p. 338.

Note 8. Tulbah, Wahbah Khattab, 1983, Ahkam Al-Iltizam Baina As-Shari'ah Al-Islamiyyah Wal Qanun, Darul Fikr Al-'Arabi-Al-Qahirah, p. 155.

Note 9. Mohd Afandi Awang Hamat, n.d. The Theory of Option (al-Khiyar) in Islamic and Malaysian Laws: A Comparative Study, Unpublished Master Dissertation, International University Malaysia, Kuala Lumpur, p. 266.

Note 10. Syed Ahmad Al-Sagoff, 1996, Principles of the Law of Contract in Malaysia, Malaysia Law Journal, p. 97.

Note 11. Beatrix Vohrah \& Wu Min Aun, 2003, The Commercial Law of Malaysia, Pearson Malaysia Sdn, Bhd., pp. 71-72.

Note 12. Mohd Afandi Awang Hamat, n. d. p. 272.

Note 13. Beatrix Vohrah \& Wu Min Aun, 2003, p. 72.

Note 14. Kamali, Mohammad Hashim, op cit. p. 328.

Note 15. Zaidan, Abdul Karim, n. d., p. 48.

Note 16. Ibid. p. 48.

Note 17. Lord Templeman, Obligations: Contract Law, Old Bailey Press, 1997, p. 90.

Note 18. Ibid

\section{Copyrights}

Copyright for this article is retained by the author(s), with first publication rights granted to the journal.

This is an open-access article distributed under the terms and conditions of the Creative Commons Attribution license (http://creativecommons.org/licenses/by/3.0/). 